\title{
Between Languages and Cultures: Arabic into English Transliteration in English Travel Literature
}

\author{
Nusaiba Adel Almahameed (Corresponding author) \\ Department of English Language and Literature, Al-Hussein Bin Talal University, Ma'an, Jordan \\ E-mail: n.almahameed@yahoo.co.uk \\ Renad Mohammad Abbadi \\ Department of English Language and Literature, Al-Hussein Bin Talal University, Ma'an, Jordan \\ E-mail: renad_a@yahoo.com \\ Atef Adel Almahameed \\ Department of Arabic Language and Literature, Al-Hussein Bin Talal University, Ma'an, Jordan \\ E-mail: atefade189@yahoo.com
}

Received: 24-04-2017

Published: 01-11-2017
Accepted: 19-06-2017

doi:10.7575/aiac.ijalel.v.6n.6p.235
Advance Access Published: September 2017

URL: http://dx.doi.org/10.7575/aiac.ijalel.v.6n.6p.235

\begin{abstract}
This essay aspires to examine the use of transliteration of some words and phrases from Arabic to English in travel literature books. This has been conducted by exploring the transliterated Arabic words and phrases, and comparing the different transliterations of the same words and phrases by different writers. It investigates the way that the travel

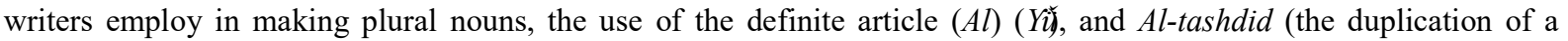
letter). The conclusion drawn is that travel literature writers resort to transliteration for three reasons; one of the main reasons is that sometimes there is no one-to-one correspondence; the second main reason suggests that transliteration avoids the loss of meaning; and the third one stems from the fact that transliteration helps to find transculturation between cultures. The contributions of this essay would be of concern to scholars, who are interested in Arabic into English transliteration, specifically in English travel literature. According to the researchers' knowledge, this essay can be considered a leading pioneer study in the field that deals with transliteration from Arabic into English in English travel literature.
\end{abstract}

Key words: Transliteration, Arabic, English Travel Literature, Culture

\section{Introduction}

A review of the literature shows that the connection between travel literature and translation has gained currency among prominent critics and scholars. However, scarce literature has been found on the study of Arabic into English transliteration in English travel literature. Transliteration is also referred to in the translation of religious and literary texts as a form of transcribing the loan word in the translation (Baker 1992). Along the same vein, George Fragopoulos (2014) tackles transliteration's own creative and literary potentialities, which he calls the metaphorical or literary transliteration. He defines literary transliteration as "the literal act itself but also a more aestheticized, [...] poeticized, version of this process that allows for a multiplicity of cultural, linguistic, and even historical registers to be made apparent" (140). In his essay, Fragopoulos seeks to show how the poetry and poetics of works of Olga Broumas and George Economou allow for productive critical excursions into the probabilities that transliteration can bestow some theories and practices that translation cannot (141).

This essay analyses the use of transliteration of some words and phrases from Arabic to English in five travel literature books, published by English travel writers in the late nineteenth and early twentieth century. The essay is mainly involved in studying some of the travel literature books that have been abandoned. It examines The Land of Gilead with Excursions in the Lebanon (1880) by Laurence Oliphant, A. Goodrich-Freer's In A Syrian Saddle (1905), The Jordan Valley and Petra (1905) by William Libbey and Franklin E. Hoskins, and Archibald Forder's Ventures Among the Arabs (1909) and In Brigands' Hands and Turkish Prisons 1914-1918 (1920). The substantial reason for choosing these travel literature books is that all of these books describe regions in Jordan. And as the research is primarily concerned with spelling and pronunciation, it is essential to study the same region and the same dialect in order to easily highlight the similarities and differences.

${ }^{1}$ See Alison E. Martin and Susan Pickford "Travel Writing and Translation" (2012), Susan Bassnett "Travelling and Translating" (2008), and Susan Bassnett, "Authenticity, Travel and Translation" (2000). 
According to the researchers' knowledge, this essay can be considered a leading pioneer study in the field that deals with transliteration from Arabic into English in English travel literature. It aims to investigate the utilisation of transliteration of some words and phrases from Arabic to English in travel literature books. This has been conducted through examining the transliterated Arabic words and phrases, and comparing the different transliterations of the same words and phrases by different writers. In addition this essay examines the way that the travel writers employ in making plural nouns, the use of the definite article $(A l)$ ( $Y \ddot{\imath}$ ), and $A l$-tashdid (the duplication of a letter).

\section{Translation versus Transliteration}

Shedding light on the differences between translation and transliteration is vitally necessary to recognise the differences between the two linguistic terms since they have several similarities in common. David Crystal (1991) defines translation as a process where "the meaning and expression in one language (source) is tuned with the meaning of another (target) whether the medium is spoken, written or signed" (p. 346). Eugene Nida and Charles Taber (1969) emphasise that (SL) and (TL) should be equivalent; "[ $\mathrm{t}$ ]ranslating consists in reproducing in the receptor language the closest natural equivalent of the source language message, first in terms of meaning and secondly in terms of style" ( $p$. 12), and "there should be a high degree of equivalence of response, or the translation will have failed to accomplish its purpose" (p. 24). Similarly, John Catford (1965) defines "translation" as "the replacement of textual material in one language (SL) by equivalent textual material in another language (TL)" (p. 20). On the contrary, transliteration is defined by Marshall Hodgson (1974) as "the rendering of the spelling of a word from the script of one language into another language" (p. 4). This view is shared by Moses Alo (1998) who defines transliteration as "the process whereby the units of one language, e.g. words, structures, are replaced by those in another" (Alo, quoted from Yeibo, 2011: 204). Furthermore, transliteration takes place in the form of lexical borrowing or in loan words as a strategy used in translation when faced with the problem of non equivalence, specifically when faced with translating culture specific words (Baker, 1992).

From the definitions of both terms, it is clearly seen that while the definition of "translation" is based primarily on conveying or interpreting the meaning in the source language (SL) by equivalent textual material into the target language (TL), "transliteration" is made possible by using one system of representing sounds; by the replacement of letters or writing a word in the characters of another language; i.e. using English alphabet to represent Arabic alphabet. The difference between "translation" and "transliteration" lies in the fact that in translation the form and content of the target text should be equivalent to the form and content of the source text, whereas transliteration is not defined by means of equivalence but it is mainly concerned with formulating words and phrases existing in one language into another.

In his important essay "Translation, Community, Utopia" (2000), Lawrence Venuti, one of the world's leading theorists of translation, highlights the problems that the translator faces throughout the process of translation:

Translation never communicates in an untroubled fashion because the translator negotiates the linguistic and cultural differences of the foreign text by reducing them and supplying another set of differences, basically domestic, drawn from the receiving language and culture to enable the foreign to be received there. The foreign text, then, is not so much communicated as inscribed with domestic intelligibilities and interests (467).

According to Venuti, translation is a complex process because it is difficult for the translator to retain the cultural and linguistic differences of the "foreign text" and instead s/he reduces these differences and adds a new set of domestic differences. So it is the "transliteration" process that can permit the transliterator to keep the cultural and linguistic differences of the "foreign text". By the same token, Fragopoulos argues that the main distinction between transliteration and translation, it is that transliteration "makes far more tangible the existence of the source language and cultural context than the translation" (141). Another complication that can be resolved by transliteration as Venuti's argument suggests is by the "inscription of the foreign text" within the values of the receiving culture as he argues:

Can a translation ever communicate to its readers the understanding of the foreign text that foreign readers have? Yes, I want to argue, but this communication will always be partial, both incomplete and inevitably slanted towards the domestic scene. It occurs only when the domestic remainder released by the translation includes an inscription of the foreign context in which the text first emerged (473).

In his journey around the coast of Britain and Northern Ireland, the American travel writer, Paul Theroux felt relief from the strictness and the accuracy of language contact as he travels within the same language:

Writing about a country in its own language was a great advantage, because in other places one was always interpreting and simplifying. Translation created a muffed obliqueness - one was always seeing the country sideways. But language grew out of the landscape - English out of England - and it seemed logical that the country could be accurately portrayed only in its own language (p. 4). 
Transliteration is contained in Theroux's words that "the country could be accurately portrayed only in its own language", which means that the meanings of certain words and phrases are best conveyed by the language of the country itself as there are cases in which there is no one to one equivalence, as will be discussed later on. Thus the shortage of translation in certain cases can only be perceived by transliteration.

From the above definitions of transliteration, it can be summerised that that transliteration is not only rendering one language's sound in the alphabets of another, but it also a communicative process through which the ideas and thought of one culture is transmitted into another culture, or in other words, it is the cultural communication. In this respect, Michael C. Onwuemene (1999) defines transliteration as

the act of thinking and conceiving in one's first language but expressing the substance thought or conceived in one's second language such that the second-language expressions used contain some salient linguistic and rhetorical implants from the first language (1058).

\section{The transliteration of 'travel experience' into 'travel literature'}

Transliteration can be considered as a textual journey that a traveller may commence to introduce foreign words and phrases into the target language and culture, and then adapt them as a way of finding a cross-cultural contact between the two cultures, two traditions, and two languages.

Travel writers such as Oliphant, Libbey, Hoskins, Forder, and Goodrich-Freer have great roles in moving between cultures and languages and introducing a great amount of Arabic transliterated words and phrases to the western culture. Knowing that they utilise different transliterated words and phrases gives rise to the question: when do these writers resort to transliteration? Examining the list of the transliterated words and phrases, used by these writers as seen in (Appendix I), shows that they use transliteration in many cases and for different reasons.

Transliteration is the only effective technique in rendering into English some Arabic names of persons and places, for example Oliphant uses transliteration for the names of some places such as Moab, Ain el Ghazal, and Arak el Emir, the place which cannot be translated, although in some cases he provides translation for some place names such as JebelelAswad (Black Mountain) the Bawwabet Allah (God's gates). However, he transliterates other place names without providing any translation even though some part of place names could be partially translated such as Kalat Zerka (which can be translated into Zarka Castle) and Wady Kefren (which can be translated into Kefren Valley). Oliphant's use of transliteration for these names of places, despite the fact that translation can be used in some cases, indicates that he aims to introduce these places to his culture in order to create transculturation between Arabic and English cultures. In this respect, Fragopoulos asserts that "[t]ransliteration enacts a simultaneous existence between cultures, languages, and geographies. It fractures any notion of pure national identity or singular national language" (148). In Libbey and Hoskins' book, names of places are also transliterated such as Rubud, El Ajlun, Jerash, Salt, Madeba, Shobek, and Kerak. Other examples of transliterated names of places can be found in Forder's books such as Kerak, Moab, Arag, Negeb, Mecca, and Kaaba. More examples of transliterated names of places can be found in Goodrich-Freer's In A Syrian Saddle as Belka, Judaea, Jebel Osha, El Bireh, Jebel ed deek (Hill of the Cock), and Rijal el-'Amud (Men of the Columns). Likewise, in the above books, Arabic names of persons are always transliterated such as Said Ibrahim, Ahmed el Rifai, Ismail el Arkawy, Daud, Abraham, Ishmael, Hagar, Mohammed, Abu Jirius, Caliph Omar, Aboo George, Abdallah, Moses, Khalil, and Koreish (tribe).

It has been noticed that the use of transliteration for Arabic names of persons and places is inevitable, as transliteration is the only possible means available for rendering these names into English, since English language is devoid of these names.

In some cases the synonym is lacked or not lexicalised in English language, which means that a word cannot be replaced by an equivalent word. In such a case, transliteration becomes the only and the inevitable technique that can be utilised to avoid the loss of meaning for words that occur in everyday language in Arabic culture. Some of these examples are some titles that prefix a person's name such as Sheikh, Imaum, Caliph, Khalif, Khuri, Haj, and Pasha which have no equivalents or exact meanings in English language.

Transliteration is also used in these books in order to maintain the full meaning of Islamic terms such as Ullah (God), Muazzin (inviter), Ghuzzu (raiding), Haram (forbidden), Sadaka, Zacat, Hajj, Surat, Hegira, Bismillah (In name of God) Rumathan (the month observed by Moslems for fasting by day and feasting by night), and Ze el Hadj, (the eighth day of the Mohammedan month). Ahmed Elimam (2013) argues that

transliteration of terms foreignises the text but possibly preserves the full meaning of the term (considering that Islamic terms such as zakah, hajj, "umrah' roughly "alms-giving," "pilgrimage," "minor pilgrimage," are known to "most" readers of the translations of the Quran), while translating terms domesticates the text but also loses some of the meaning of the respective terms (p. 34).

Elimam gives an example of the word zakah which is transliterated as "zakat" and translated as "regular charity" and as "the poor- due". He adds that the translator Ahmed Ali "opts for transliteration and explanation as follows: "give zakat (the due share of your wealth for the welfare of others)" (p.35). Thus transliteration with explanation is needed when using Islamic terms as these terms are missing from English language. 
Throughout examining the transliterated words that are used by the above travel writers, it has been noticed that some words do not only lack equivalence in English language, but also do not exist in English culture, that is why they are transliterated with explanation. These words include kuffeiheh (head covering with a goats hair), akal (rope to keep it in place), the abeih (Arab cloak), shig (place especially set apart for the entertainment of guest), semen, (this is a preparation of milk first boiled, then hung, then churned in a sheep-skin by women, who suspend it to a stick, and then keep pulling it to and fro until it attains the consistency of clarified butter), hasheesh (a form of opium), and tomnbak (the special tobacco used for the narghil).

As transliteration can be considered a textual journey, it helps travellers not only to survive the journey, but also to survive the text by introducing it to their own cultures and as a result finding a cross-cultural contact between cultures. This can be achieved by transliterating the words and phrases of the source language, then providing equivalences in the target language. Many examples of this process are found in the above books, where the travel writers translate the Arabic words and phrases and then provide the English equivalences, such examples include: Leben (sour-milk), Zakir: external observances (the outward), ilBatin: internal feeling (the inward), Mezra'a, Ya ibny (Oh, my son!), Manzul (Public guest-house), Fakireh (poor), Tezkereh, Yowmel-Jumma (the day of gathering), Kurrey-ya-tayn (two villages), Kismet (Fate), Mutesarrif (governor), Alhamdul-Illah, (God be thanked), wain es-Sitt? (Where is the Lady?), majnoon (the name which the Arabs give to the half-crazy men, generally derwishes), iumkin inshallah (Perhaps, if God will), bookra or baadbookra (to-morrow, or after to-morrow), Ana baraf? Allah baraf (Do I know? God knows), fellahin (Arab peasants), Dieb (wolf), Lehaf (wadded cotton quilt), Beit (the house), El-Ghor (The Rift), baad wahad saar (after half-an-hour), baad wahad saa (after one hour), ba'ad nus saa (after half-an-hour), ba'ad chamseh saa (after a quarter of an hour).

Having explored the cases in which the travel writers employ transliteration, it is important to illuminate some of the linguistic devices that are commonly and remarkably used by these writers. The remainder of this paper proceeds as follows: first, it examines the way that these travel writers follow to form the Arabic plural nouns. Next, it looks over the employment of the definite article $(A l)$ in their travel writings. Finally, it discusses their use of Al-tashdid (the duplication of a letter).

Before discussing the rule that the travel writers apply in forming plural nouns, it is necessary to light up the difference between the noun plural system in Arabic and in English. There are two distinct modes of plural formation in Arabic: the sound plurals and broken plurals. The sound plurals are formed by appending suffixation of masculine +uun or feminine taat to the same root (e.g. mudarres $\rightarrow$ mudarresuun and mudarresaat). Contrastingly, broken plurals primarily involve internal modification of the singular root (e.g film $\rightarrow$ aflam). As Karin Ryding (2005) clarifies that the broken or internal plural "involves a shift of vowel patterns within the word stem itself, as in English 'man/men,' 'foot/feet' or 'mouse/ mice'. It may also involve the affixation of an extra consonant (usually hamza or waaw)" (p. 144). By contrast, in English, plural nouns are usually formed by adding -s to the end of the word however there are several exceptions to this rule.

Some of the Arabic plural nouns that are used by the travel writers are as follow: fellaheen (the masculine sound plural of fellah) and it can be said that it is the only noun that are pluralised correctly, while the other nouns, which need broken plural, are pluralised by applying the English rule on Arabic words through adding -s to the end of the word such as Imaum $\rightarrow$ Imaums intead of A'emah, Sheikh $\rightarrow$ Sheikhs instead of Shoyoukh, Hammams instead of Hamammat, Babooshes instead of Bawabeej. The conclusion to be drawn from applying the English plural rules on Arabic words are that either the travel writers are not exposed to or are unfamiliar with the plural forms of these words, or that making broken plural is a difficult process for non-native Arabic speakers so they add -s to indicate that these words are plural.

The second linguistics device that attention should be paid to is the employment of the definite article (Al) (ال). The definite article in Arabic (Al) (ال) is equivalent to the definite English article 'The'. However in Arabic it never occurs independently; it is attached to the word and it is used as a prefix.

It has been noticed that the travel writers use different pronunciations of the definite article $(A l)$, and this refers to a grammatical rule in Arabic language. This rule states that

The nature of the first letter of a noun or adjective determines the pronunciation of /al/. The letters of Arabic alphabet are divided into two sections, one section whose members assimilate the /1/ sound and another section whose members allow the full pronunciation of $/ 1 /$ of the definite article (Ryding, p. 157).

The first section is called Sun letters (Huruuf shamsiyyah حروف شمسيّة). When these sounds or letters begin a word, "they cause laam of the definite article to assimilate or be absorbed into them in pronunciation (but not in writing)" (Ibid, p. 157). The effect of this assimilation is the duplication of the first letter of the word. That letter is then doubled and indicated by a shadda or the doubling marker () above it, and is pronounced more strongly. The Sun letters include the following alphabets:

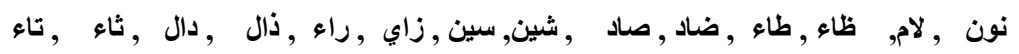

taa', thaa', daal, dhal, raa', zay, siin, shin, saad, daad, taa' zaa', laam, nuun

To clarify this rule, the table below shows some of the sun letters with examples: 


\begin{tabular}{|c|c|c|c|c|c|}
\hline \multicolumn{2}{|c|}{ Sun Letters } & \multirow{2}{*}{$\begin{array}{l}\text { English } \\
\text { Apple }\end{array}$} & \multirow{2}{*}{$\begin{array}{l}\text { Arabic } \\
\text { التّفاحةة }\end{array}$} & \multirow{2}{*}{$\begin{array}{l}\text { Spelling } \\
\text { Al-tufaha }\end{array}$} & \multirow{2}{*}{$\begin{array}{l}\text { pronunciation } \\
\text { At-tifaha }\end{array}$} \\
\hline تاء & taa' & & & & \\
\hline ثاء & thaa' & Clothes & النُّاب & Al-theyab & Ath-theyab \\
\hline دال & daal & Bear & الدّب & Al-dub & Ad-dub \\
\hline ذال & dhaal & Fox & الذّبّب & Al-dha' lab & Adh-dha ${ }^{e}$ lab \\
\hline راء & raa' & Spring & الرّبيع & Al-rabiie & Ar-rabiie \\
\hline زاي & zay & Oil & الزّيت & Al-zait & Az-zait \\
\hline سين سين & siin & Fish & السّمك & Al-samak & As-samak \\
\hline شين & shiin & Sun & الثُمس & Al-shams & Ash-shams \\
\hline لام & laam & Night & اللّيل & Al-lail & Al-lail \\
\hline 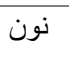 & nuun & light & النّور & Al-noor & An-noor \\
\hline
\end{tabular}

Having examined the use of the definite article $(A l)$ followed by the Sun Letters by the travel writers, it has been observed that they mix between pronunciation and writing; when they use words that begin with Sun letters, the laam of the definite article has been assimilated into the Sun letters in pronunciation as well as in writing, for example, instead of writing Al-salt, Froder lets the laam of the definite article to be absorbed into writing and writes it as Es-Salt and Jebel ed deek instead of Jebel Al-deek. Similarly, in In A Syrian Saddle, the laam of the definite article has been assimilated into the Sun letters, Goodrich-Freer writes Ain es-Shech instead of Ain Al-shech, and wain es-Sitt instead of wain Al-sit. It seems that the travel writers depend upon the accent and the pronunciation of the speakers rather than on applying the grammatical rule.

The second section of the letters is called Moon letters (Huruuf qamariyya قمريّة). When the definite article (Al) (ال) is attached to words that begin with Moon letters, the laam of the definite article is not assimilated or is absorbed but it keeps its pronunciation. The following list of the alphabet is classified according to the Moon letters:

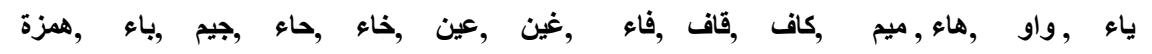

hamza, baa', jiim, Haa', xaa', ‘ayn, ghayn, faa', qaaf, kaaf, miim, haa', waaw, yaa'

\begin{tabular}{|c|c|c|c|c|c|}
\hline \multicolumn{2}{|c|}{ Moon Letters } & \multirow{2}{*}{$\begin{array}{l}\text { English } \\
\text { The door }\end{array}$} & \multirow{2}{*}{$\begin{array}{l}\text { Arabic } \\
\text { الباب }\end{array}$} & \multirow{2}{*}{$\begin{array}{l}\text { Spelling } \\
\text { Al-bab }\end{array}$} & \multirow{2}{*}{$\begin{array}{l}\text { pronunciation } \\
\text { Al-bab }\end{array}$} \\
\hline باء & baa' & & & & \\
\hline جيم & jiim & The camel & الجمل & Al-jamal & Al-jamal \\
\hline حاء & Наa' & The field & الحقل & Al-Haqel & Al-Haqel \\
\hline خاء & xaa' & Thursday & الخميس & Al-xamiis & Al-xamiis \\
\hline عين & 'ayn & Iraq & العر اق & Al- iraaq & Al-'iraaq \\
\hline غين & ghayn & The cloud & الغيمة & Al-ghayma & Al-ghayma \\
\hline فاء & faa' & The butterfly & الفر اشة & Al-farasha & Al-farasha \\
\hline قاف & qaaf & The village & القريّة & Al-qarya & Al-qarya \\
\hline ميم & miim & The Moon & القمر & Al-qamar & Al-qamar \\
\hline ياء & yaa' & Right & اليمين & Al-yamiin & Al-yamiin \\
\hline
\end{tabular}

Concerning the use of the define article (Al) (ال) followed by Moon letters, it has been noticed that the travel writers apply it more correctly than the one followed by the Sun letters, as for instance Arab-el-mudn and Rijal el-'Amud by Forder; El Caaba, Ze el Hadj, Jebelel-Aswad, El-Ghor, Ain el Ghazal, Arak el Emir and ilBatin by Oliphant.

Furthermore, in other cases they use the definte article (The) instead of (Al), for example, The Khalif, The khateeb, The Caliph, the abeih, the Dukkan, the Sultan, and the Sheikh. Moreover, the English define article the is used in some cases while in fact the Arabic word does not take an article, such as the Bawwabet Allah instead of Bawwabet Allah, here the English grammatical rule has been applied.

The final linguistics device that has been utilised by the travel writers is Al-tashdid which means:

When a letter is doubled, the mark called tashdìd, which signifies corroboration, is placed over it. Thus, in the word شدّت shid-dat, where the first syllable ends with دd, instead of following the natural mode of writing, as, شددت, the two dāls are united, and the mark indicates this union (Forbes, 1863, p. 15). 
With regard to the use of Al-tashdid in travel literature, it seems that the travel writers also face difficulties in determining how and when to use Al-tashdid. For example, Oliphant uses it correctly in fellaheen, fellah, fellaha, feddan, hammams, and Dukkan by doubling the letters, however; in Kuffeiheh and kufeiyeh (f́mzä), the same word is pronounced differently and incorrectly in each time. In the first case, he doubles the $(f)$ letter and in the second one he does not double any, while the (ياء, yaa') is the letter which should be doubled (Kufeyyah). The same mistake has been found in Goodrich-Freer's book, where Kufeyyah is pronounced as keffeeye. Similar to Oliphant, Forder uses Al-tashdid correctly in some words such as Mohammed, Mecca, Muazzin, and incorrectly in Ghuzzu and Kurrey-ya-tayn; in Ghuzzu (! $\delta q)$ and Kurrey-ya-tayn (5Ngt), where there is no Tashdid and no letters should be doubled. However, he does not double the /j/ letter in Haj (Pilgrim: حاجّ) while it should be doubled. The same word has been pronounced correctly by Libbey and Hoskins (Hajj Ismail). More interestingly, the word (Mutasarrif: متصرّف) has been used by three writers; it is pronounced correctly by Libbey and Hoskins as Mutaserrif and by Goodrich-Freer Mutesarrif, but incorrectly by Oliphant who doubles /s/ instead of /r/ Mutessarif.

As have been noted above different transliterations can be found for the spelling of the same Arabic words even within the same book. This may relate to the fact that the travel writers do not follow the grammatical rule of Al-tashdid, but they depend on the Arabic dialects which differ in pronunciation even within the same county. (See Appendix I for more examples of different pronunciation of the same word).

\section{Conclusion}

By way of concluding, it can be suggested that the use of transliteration in travel literature can be used as a communicative bridge between cultures and languages. As there is no one-to-one correspondence between some of Arabic and English words and phrases, transliteration solves the problem of translation, and incorporates culturally significant words and phrases from other languages. Furthermore, some of the concepts are culturally specific, such as Alsharia or the religious concepts, in addition to some titles that prefix a person's name. Thus, to avoid the loss of the meaning, and to capture the full meaning of the text, travel writers resort to transliteration.

Above and beyond all other consideration, transliteration from Arabic into English is a difficult task. That is to conclude that the multiple transliterations of the same words is due to three reasons; the first one refers to the phonetic incompatibilities between Arabic and English; the second reason mainly refers to the differences in the sound and writing systems; and the third reason is primarily concerned with the travel writers' dependence on the Arabic dialects, which vary even among the same country, rather than on following and applying the grammatical rules.

\section{Recommendations}

In the light of the discussion and conclusion, the researchers highly recommend expanding the scope of the study to include studying transliteration of other Arabic linguistic devices such as Al-hamza (glottal stop semi-consonant) and Al-mad (a glottal stop /?/ followed by a long /a:/).

It is strongly recommended to investigate whether the travel writers still depend on dialects while transliterating or apply grammatical rules.

Finally, the present research is but one step on a long road that should aim at studying Arabic to English transliteration in English travel literature not only in the books, that have been abandoned, but in other genres and throughout different periods of time.

\section{References}

Baker, M. (1992). In Other Words: a Coursebook on Translation, Routledge, London.

Bassnett, S. (2000). “Authenticity, Travel and Translation”. In Mira Kadric, Klaus Kaindl and Franz Pöchhacker (Eds.), Translationswissenschaft: Festschrift für Mary Snell-Hornby zum 60. Geburtstag. Tubingen: Stauffenberg. 104-14.

Bassnett S. (2008). “Travelling and Translating”. Journal of Postcolonial Writing 40. 2: 66-76.

Casey, B. (2015). The Double Life of Laurence Oliphant: Victorian Pilgrim and Prophet. New York: Post Hill Press.

Catford, J. C. (1965). A Linguistic Theory of Translation. United Kingdom: Oxford University Press.

Crystal, D. (1991). The Cambridge encyclopedia of language. United Kingdom Cambridge University Press.

Elimam, A. S. (2013). Marked Word Order in the Qurān and its English Translations: Patterns and Motivations. UK: Cambridge Scholar Publishing.

Forbes, D. (1863). A Grammar of the Arabic Language: Intended More Especially for the Use of Young Men Preparing for the East India Civil Service, and Also for the Use of Self-instructing Students in General. London: W.h. Allen.

Forder, A. (1920). In Brigands' Hands and Turkish Prisons 1914-1918. (London and New York: Marshall Brothers)

Forder, A. (1909). Ventures Among the Arabs, in Desert, Tent, and Town. (New York: Gospel Publishing House).

Fragopoulos, G. (2014). "The Politics and Poetics of Transliteration in the Works of Olga Broumas and George Economou." MELUS. Volume 39, Number 4, pp. 140-161.

Goodrich-Freer, A. (1905). In A Syrian Saddle. London: Methuen \& CO.

Hodgson, M. (1974). The Venture of Islam. University of Chicago press. 
Libbey, W. and Hoskins, F. (1905). The Jordan Valley and Petra. V1 of 2 (London and New York: The Knickerbocker Press).

Matin, A., \& Pickford, S. (2012). "Travel Writing and Translation”. In Alison E. Martin and Susan Pickford (Eds.), Travel Narrative in Translation 1750-1830 United Kingdom: Routledge. 1-26.

Nida, E. A., \& Taber, C. R. (1969). The Theory and Practice of Translation. Leiden: E. J. Brill.

Oliphant, L. (1880). The Land of Gilead with Excursions in the Lebanon. Edinburgh and London: William Blackwood and Sons.

Onwuemene, Michael C. (1999). "Limits of Transliteration: Nigerian Writers' Endeavors toward a National Literary Language." PMLA 114.5. pp. 1055-66.

Ryding, K. C. (2005). A Reference Grammar of Modern Standard Arabic. Cambridge: Cambridge University Press.

Theroux, P. (2006). Kingdom by the Sea: A Journey Around the Coast of Great Britain. New York: Houghton Mifflin Company.

Venuti, L. (2000). “Translation, Community, Utopia.” In The Translation Studies Reader. L. Venuti (Ed.). London: Routledge. 468-88.

Yeibo, E. (2011). "Nativization of English in African Literary Texts: A Lexico-semantic Study of Transliteration in Gabriel Okara's The Voices". International Journal of Humanities and Social Sciences 1:13. pp. 202-208.

\section{(Appendix I)}

Laurence Oliphant. (1880). The Land of Gilead with Excursions in the Lebanon.

\begin{tabular}{|c|c|c|}
\hline Transliterated Word / Phrase & Explanation & $\begin{array}{r}\text { Pag } \\
\text { e Number }\end{array}$ \\
\hline Sheikh & leading man & 28 \\
\hline Sheikh & & xiv \\
\hline Imaum & & 9 \\
\hline Imaums & & 9 \\
\hline Hegira & & 30 \\
\hline Fellaheen & peasants & 37 \\
\hline tarboosh & & 38 \\
\hline kuffeiheh & & 46 \\
\hline khan & & 46 \\
\hline chic & & 53 \\
\hline semen & $\begin{array}{l}\text { This is a preparation of milk first boiled, then } \\
\text { hung, then churned in a sheep-skin by women, } \\
\text { who suspend it to a stick, and then keep pulling it } \\
\text { to and fro until it attains the consistency of } \\
\text { clarified butter. }\end{array}$ & 60 \\
\hline Minenzil & & 72 \\
\hline Mutessarif & governor & 72 \\
\hline the abeih & Arab cloak & 112 \\
\hline kufeiyeh & head-dress & 112 \\
\hline Backsheesh & $\begin{array}{l}\text { it seemed a greater discovery to find a } \\
\text { native of Palestine who did not know the meaning } \\
\text { of the word backsheesh than it was to identify the } \\
\text { site of an ancient city. }\end{array}$ & 118 \\
\hline Leben & sour-milk & 144 \\
\hline Marhaba & $\begin{array}{l}\text { They always greeted us with a cordial } \\
\text { salutation of 'Marhaba' }\end{array}$ & 190 \\
\hline Jebel Ajlun, & Place & 198 \\
\hline Moab & Place & 205 \\
\hline Ain el Ghazal & Place & 236 \\
\hline Kalat Zerka & Place & 238 \\
\hline Gulf of Akaba & Place & 239 \\
\hline the Dukkan & shops & 247 \\
\hline Arak el Emir & & 279 \\
\hline Wady Kefren & & 280 \\
\hline fellah & & 296 \\
\hline fellaha & & 322 \\
\hline feddan & & 330 \\
\hline Emir & & 344 \\
\hline
\end{tabular}




\begin{tabular}{|c|c|c|}
\hline \multicolumn{1}{|l|}{ Chef } & & 349 \\
\hline khamsin & & 362 \\
\hline Sheikh & & 375 \\
\hline Tarboosh & external observances (the outward) & \\
\hline Zakir & internal feeling(the inward) & \\
\hline ilBatin & & 382 \\
\hline Fatimite Khalifs of Egypt & 383 \\
\hline the Khalif Haroun al Raschid & & 397 \\
\hline El Caaba & the eighth day of the Mohammedan month & 397 \\
\hline Ze el Hadj & Black Mountain & 418 \\
\hline Jebelel-Aswad & God's gates & 426 \\
\hline the Bawwabet Allah & & 426 \\
\hline hammams & & 426 \\
\hline khans & Sheikh Said Ibrahim / Sheikh Ahmed el & 434 \\
\hline Sheikh & & \\
\hline the Sheikh Bedawi & the leather of slippers & 434 \\
\hline the Sheikh el Bedawi & & 435 \\
\hline babooshes & milk spring & 456 \\
\hline snowy Jebel & & 466 \\
\hline Neba-el-Leben & & 477 \\
\hline Mezra'a & & 480 \\
\hline the Sultan & & 520 \\
\hline
\end{tabular}

William Libbey and Franklin E. Hoskins. (1905). The Jordan Valley and Petra.

\begin{tabular}{|c|c|c|}
\hline Transliterated Word / Phrase & Explanation & $\begin{array}{l}\text { Page } \\
\text { Number }\end{array}$ \\
\hline Mutaserrif & Mutaserrif of Kerak, to take us down to Petra & 5 \\
\hline Ya ibny & (Oh, my son!) & 94 \\
\hline Manzul & Public guest-house & 98 \\
\hline Khan & $\begin{array}{l}\text { It is a large khan, with many rooms for man and } \\
\text { beast }\end{array}$ & 98 \\
\hline Hajj & $\begin{array}{l}\text { Hajj It is under the care of the family of the Hajj } \\
\text { Ismail el Arkawy }\end{array}$ & 98 \\
\hline Emir & the Emir of the Arabs in the Jaulan & 99 \\
\hline Sheikhs & Several sheikhs & 100 \\
\hline salaams & $\begin{array}{l}\text { May God recompense you (in this sorrow) by your } \\
\text { own safety and peace, May God preserve you. }\end{array}$ & 101 \\
\hline Bedawy & Bedawy horsemen & 128 \\
\hline Khuri & At Tabigha we saw one specimen " the Khuri Daud" & 132 \\
\hline Abadiyeh & $\begin{array}{l}\text { Abadiyeh is a village of mud-brick houses, built on a } \\
\text { conical mound }\end{array}$ & 137 \\
\hline Fakireh & poor & 138 \\
\hline Sheikh & the Sheikh of the village & 240 \\
\hline Tezkereh & $\begin{array}{l}\text { And was The Jordan Valley and Petra forced to ask } \\
\text { us outright about our tezkereh }\end{array}$ & 282 \\
\hline Pasha & $\begin{array}{l}\text { Nazim Pasha, Rustem Pasha, Muhammad } \\
\text { Said Pasha, Rasheed Pasha }\end{array}$ & 316 \\
\hline Arabah & & 325 \\
\hline Sultan & & 326 \\
\hline the Mount of Olives & & 330 \\
\hline $\begin{array}{l}\text { Rubud, El Ajlun, Jerash, Salt, } \\
\text { Madeba, and Shobek, then from } \\
\text { Kerak across to the seacoast again at } \\
\text { Gaza. Kerak, with its outpost at } \\
\text { Shobek }\end{array}$ & & 337 \\
\hline
\end{tabular}


Archibald Forder. (1909). Ventures Among the Arabs, in Desert, Tent, and Town.

\begin{tabular}{|c|c|c|}
\hline $\begin{array}{l}\text { Transliterated Word / } \\
\text { Phrase }\end{array}$ & Explanation & $\begin{array}{l}\text { Page } \\
\text { Number }\end{array}$ \\
\hline Kerak & & 1 \\
\hline Moab & & 2 \\
\hline Ishmael & & 2 \\
\hline Medeba & & 9 \\
\hline Abraham & & 24 \\
\hline Hagar & & 25 \\
\hline Keraki & & 34 \\
\hline Beyrout & this man had lived in Damascus and Beyrout & 41 \\
\hline Skour & the next tribe,the Skour & 47 \\
\hline Ullah & God & 67 \\
\hline Ghuzzu & Our chiefs had gone on "ghuzzu," & 83 \\
\hline $\begin{array}{l}\text { "You are Bedr, you Mc-mood, and } \\
\text { you Salamey," three of the cruelest } \\
\text { and most bloodthirsty of our tribe. }\end{array}$ & & 92 \\
\hline Fellah & a young man named Fellah & 94 \\
\hline Sheikhs & Several sheikhs & 100 \\
\hline Dawimee & $\begin{array}{l}\text { we came to a large village named } \\
\text { Dawimee. }\end{array}$ & 122 \\
\hline Negeb & $\begin{array}{l}\text { Dry and desolate region known as } \\
\text { the Negeb. }\end{array}$ & 125 \\
\hline Arag & (For Iraq) & 136 \\
\hline $\begin{array}{l}\text { Es-Salt "Ramoth-Gilead" and } \\
\text { Gerash, and on to Edrei in Bashan. }\end{array}$ & & 155 \\
\hline Kurrey-ya-tayn & which means two villages & 170 \\
\hline Sheikh & Chief man & 171 \\
\hline Rumathan & $\begin{array}{l}\text { As it was Rumathan the month observed by } \\
\text { Moslems for fasting by day and feasting by } \\
\text { night }\end{array}$ & 210 \\
\hline Bismillah (In name of God) & $\begin{array}{l}\text { saying in a loud voice, "Bismillah!" } \\
\text { "In the name of God", "he told all to } \\
\text { eat, and the men began to feast". }\end{array}$ & 220 \\
\hline salaams & respects & $231-232$ \\
\hline Caaba & the Caaba, the sacred temple at Mecca & 248 \\
\hline Koreish & this tribe & 248 \\
\hline Muazzin & inviter & 250 \\
\hline Abba & cloak & 261 \\
\hline Yowmel-Jumma & the day of gathering & 265 \\
\hline Arab-el-mudn & Arab-el-mudn, the dwellers in houses & 282 \\
\hline Bedouy & Call a town or village dweller a Bedouy & 282 \\
\hline Canaan & on their way to Canaan & 286 \\
\hline
\end{tabular}

Archibald Forder (1920). In Brigands' Hands and Turkish Prisons 1914-1918.

\begin{tabular}{|l|c|c|}
\hline \multicolumn{1}{|c|}{ Transliterated Word / Phrase } & Explanation & $\begin{array}{c}\text { Page } \\
\text { Number }\end{array}$ \\
\hline Moab & & 5 \\
\hline Kerak & & 5 \\
\hline Abu Jirius & & 5 \\
\hline hasheesh & a form of opium & 26 \\
\hline Sultan & & 31 \\
\hline Beyroutto Damascus, & Hasheesh smokers & 34 \\
\hline hasheesh & Father of George & 42 \\
\hline Aboo George & Jamal Pasha & 61 \\
\hline Pasha & & 84 \\
\hline Bawdee & & 92 \\
\hline Sheikh & & 109 \\
\hline lebn 'layk' & Peace to you & 109 \\
\hline Salaam 'ay' & 109 \\
\hline He replied with 'Allah sellam-ak' & God grant you peace & 114 \\
\hline Maaney & & \\
\hline
\end{tabular}




\begin{tabular}{|l|l|c|}
\hline Aboo Jerius & & 126 \\
\hline The Caliph & Inviters & 204 \\
\hline Muezzim & & 204 \\
\hline Zacat & & 205 \\
\hline Sadakat & & 205 \\
\hline Rumathan & & 206 \\
\hline Surat & & 206 \\
\hline Caliph Omar & & 206 \\
\hline Surat 3 of the Koran & & 206 \\
\hline Mecca & Pilgrim & 207 \\
\hline Kaaba & Peace be to you & 207 \\
\hline Haj & "To you be peace & 208 \\
\hline Salaam-a-layk, & place especially set apart for the & 220 \\
\hline and the answer, Alayk-essalaam & pries & 220 \\
\hline shig & Fate & 262 \\
\hline The khateeb & Who is there? & 263 \\
\hline Kismet & In the name of God & 278 \\
\hline Man Hatha & raiding & 286 \\
\hline Bismillah & & 287 \\
\hline ghuzzu & camel & 291 \\
\hline Fatmi & & 298 \\
\hline Naga & 302 \\
\hline Harems & & \\
\hline
\end{tabular}

A. Goodrich-Freer (1905). In A Syrian Saddle.

\begin{tabular}{|l|l|c|}
\hline $\begin{array}{l}\text { Transliterated Word } \\
\text { Phrase }\end{array}$ & Explanation & Page Number \\
\hline keffeeye & head covering with a goats hair & 4 \\
\hline akal & rope to keep it in place & 4 \\
\hline Wady & the Wady Kelt & 15 \\
\hline wain es-Sitt? & Where is the Lady? & 25 \\
\hline Haram & forbidden & 28 \\
\hline Bedawy & & 28 \\
\hline tomnbak & the special tobacco used for the narghil & 30 \\
\hline Khalil & & 30 \\
\hline Madaba & & 32 \\
\hline Mount Nebo & & 42 \\
\hline Moses & & 42 \\
\hline Moab & & 43 \\
\hline the fertile Ard Abdallah & & 46 \\
\hline Abdallah & & 46 \\
\hline Bedu & & 67 \\
\hline Mecca & & 72 \\
\hline Haifa & & 72 \\
\hline Haj & pilgrim & 74 \\
\hline To go to the gate of God & Bab-el Allah & 76 \\
\hline haji & pilgrims & 172 \\
\hline mudir & We were close by the house of the mudir & 131 \\
\hline $\begin{array}{l}\text { Bedu / fellahin / Mutesarrif / } \\
\text { Hauran }\end{array}$ & $\begin{array}{l}\text { More serious cases are taken by both Bedu and fellahin } \\
\text { before the Mutesarrif (Governor) of Hauran }\end{array}$ & 135 \\
\hline Alhamdul-Illah & God be thanked & 151 \\
\hline heesh & $\begin{array}{l}\text { tobacco known as “wain,” from the Arabic word for the } \\
\text { forests where it is cultivated. }\end{array}$ & 157 \\
\hline majnoon & $\begin{array}{l}\text { the name which the Arabs give to the half-crazy men, } \\
\text { generally derwishes }\end{array}$ & 162 \\
\hline Ain es-Shech & & 167 \\
\hline Belka & & 171 \\
\hline Judaea & & 179 \\
\hline Jebel Osha & Perhaps, if God will & 181 \\
\hline El Bireh & & 173 \\
\hline iumkin inshallah & & \\
\hline & & \\
\hline
\end{tabular}


IJALEL 6(6):235-245, 2017

\begin{tabular}{|c|c|c|}
\hline bookra or baadbookra & to-morrow, or after to-morrow & 182 \\
\hline Ana baraf? Allah baraf & Do I know? God knows & 182 \\
\hline Jebel ed deek & Hill of the Cock & 187 \\
\hline Rijal el-'Amud, & Men of the Columns & 190 \\
\hline fellahin & Arab peasants & 293 \\
\hline Dieb & wolf & 294 \\
\hline Lehaf & wadded cotton quilt & 312 \\
\hline Beit & the house & 315 \\
\hline El-Ghor & The Rift & 328 \\
\hline baad wahad saar & after half-an-hour & 331 \\
\hline baad wahad saa & after one hour & 334 \\
\hline ba'ad nus saa & after half-an-hour & 335 \\
\hline $\begin{array}{l}\text { ba'ad chamseh } \\
\text { saa }\end{array}$ & after a quarter of an hour & 335 \\
\hline
\end{tabular}

